\title{
Coronavirus Disease 2019 (COVID-19) and Transplantation: Pharmacotherapeutic Management of Immunosuppression Regimen
}

This article was published in the following Dove Press journal:

Therapeutics and Clinical Risk Management

\author{
Mahtabalsadat Mirjalili (D) \\ Mojtaba Shafiekhani (iD) ${ }^{1,2}$ \\ Afsaneh Vazin (iD) \\ 'Department of Clinical Pharmacy, \\ Faculty of Pharmacy, Shiraz University of \\ Medical Sciences, Shiraz, Iran; ${ }^{2}$ Shiraz \\ Organ Transplant Center, Abu-Ali Sina \\ Hospital, Shiraz University of Medical \\ Sciences, Shiraz, Iran
}

\begin{abstract}
The 2019 novel coronavirus disease (COVID-19) was first detected in Wuhan, Hubei Province, China, in late 2019. Since then, COVID-19 has spread to more than 200 countries in the world, and a global pandemic has been declared by the World Health Organization (WHO). At present, no vaccines or therapeutic regimens with proven efficacy are available for the management of COVID-19. Hydroxychloroquine/chloroquine, lopinavir/ritonavir, ribavirin, interferons, umifenovir, remdesivir, and interleukin antagonists, such as tocilizumab, have been recommended as potential treatment options in COVID-19. Transplant patients receiving immunosuppressant medications are at the highest risk of severe illness from COVID-19. At the same time, with regard to receiving polypharmacy and immunosuppressants, treatment options should be chosen with more attention in this population. Considering drug-drug interactions and adverse effects of medications used for the treatment of COVID-19, such as QT prolongation, the dose reduction of some immunosuppressants or avoidance is recommended in transplant recipients with COVID-19. Thus, this narrative review describes clinically important considerations about the treatment of COVID-19 and immunosuppressive regimens regarding modifications, side effects, and interactions in adult kidney or liver allograft recipients.
\end{abstract}

Keywords: SARS-CoV-2, COVID-19, liver transplant, kidney transplant, immunosuppressive, transplantation

\section{Introduction}

Severe acute respiratory syndrome coronavirus 2 (SARS-CoV-2) is a novel virus which was first detected in humans in late December $2019^{1}$ Its emergence was first reported in Wuhan, Hubei Province, China, followed by a large outbreak in that country. ${ }^{1,2}$ By January 2020, a global public health emergency had been announced by the World Health Organization (WHO) and two months later, in March, the WHO declared the coronavirus outbreak a global pandemic. By May 28, 2020, a total number of 5,593,631 cases and 353,334 confirmed deaths caused by COVID-19 had been reported by the WHO. Since then, COVID-19 has continued to spread, and cases are currently reported in 203 countries. $^{3}$

Transplant patients receiving immunosuppressive therapy are at the highest risk of severe illness from COVID-19. The prevalence of human coronavirus (HCoV) was $8.8 \%$ in immunocompetent vs $4.5 \%$ in immunocompromised patients. ${ }^{4}$ In another study evaluating 540 bronchoalveolar lavage (BAL) samples from patients in a 20-month period, more than half of the patients diagnosed with HCoV were solid organ recipients. ${ }^{5}$ Studies have also been published in Spain and Italy, as

Afsaneh Vazin

Department of Clinical Pharmacy, Faculty of Pharmacy, Shiraz University of Medical Sciences, Shiraz, Iran

TellFax +987I32424255

Email vazeena@sums.ac.ir 
active centers in solid organ transplantation in Europe, evaluating transplanted patients with COVID-19. ${ }^{6,7}$ So, a balance is needed between optimal and safe immunosuppression regimens to maintain graft function and the management of COVID-19. Two of the most important challenges ahead are modifying immunosuppressive regimens and the management of drug interactions, as well as adverse events of treatment options for COVID-19 in transplant patients. Considering the novelty of COVID19 and the lack of valid randomized clinical trials regarding its treatment, particularly the management of transplant patients, this study aims to review the published articles and interim guidelines in this regard. Because of the limited experience on COVID-19 in transplant recipients, the following points are based on studies conducted so far on this disease and also previous articles regarding severe acute respiratory syndrome coronavirus (SARSCoV-1) and Middle East respiratory syndrome-related coronavirus (MERS-CoV). On the other hand, more attention should be paid to therapeutic interventions for these patients, particularly in the ICU setting and ensuring safe medication use. $^{8}$ Thus, this review describes clinical important considerations about the treatment of COVID-
19 and immunosuppressive regimens, regarding modifications, side effects, and interactions in adult kidney or liver allograft recipients.

Table 1 shows a summary of medications which are used or suggested for the management of COVID-19 patients, according to recent studies. In stable patients who can be treated as outpatients, monotherapy with chloroquine/hydroxychloroquine (with doses mentioned in Table 1) or combination therapy with oseltamivir in high-risk areas for H1N1 outbreaks is suggested. Based on interim guidelines from China and Belgium, in patients with unstable respiratory conditions (respiratory rate $>30$ breaths $/ \mathrm{min}, \mathrm{PaO}_{2}<93 \%$, or extensive pulmonary infiltration) who need to be admitted to hospital because of SARS, chloroquine/hydroxychloroquine in combination with lopinavir/ritonavir after the discontinuation of chloroquine/hydroxychloroquine, with or without ribavirin, or using remdesivir and interleukin (IL) antagonists, such as tocilizumab, is suggested. ${ }^{9,10}$ However, some guidelines may advise against these suggestions.

\section{Immunosuppressive Modifications}

The data regarding modification of the immunosuppressive regimen in transplant patients with COVID-19 are limited;

Table I A Summary of Medications Used for Management of COVID-19 Patients

\begin{tabular}{|c|c|c|c|c|}
\hline Drugs & $\begin{array}{l}\text { Pharmacologic } \\
\text { Category }\end{array}$ & Mechanism of Action & $\begin{array}{l}\text { Dosage Regimen in } \\
\text { COVID-19 }\end{array}$ & References \\
\hline Lopinavir/Ritonavir & $\begin{array}{l}\text { Antiretroviral } \\
\text { agent }\end{array}$ & $\begin{array}{l}\text { Lopinavir is an HIV-I protease inhibitor; ritonavir } \\
\text { increases the half-life of lopinavir via inhibiting } \\
\text { cytochrome P450 }\end{array}$ & $\begin{array}{l}400 \mathrm{mg} / 100 \mathrm{mg} \text { twice daily for } \\
7-14 \text { days }\end{array}$ & 39,40 \\
\hline $\begin{array}{l}\text { Chloroquine/ } \\
\text { Hydroxychloroquine }\end{array}$ & $\begin{array}{l}\text { Antimalarial } \\
\text { (aminoquinoline) }\end{array}$ & $\begin{array}{l}\text { Chloroquine inhibits quinine reductase, an } \\
\text { essential enzyme for biosynthesis of sialic acid, } \\
\text { which is necessary for virus fusion with host cell }\end{array}$ & $\begin{array}{l}\text { Chloroquine: } 400 \mathrm{mg} \text { daily for } \\
\text { I0-14 days } \\
\text { Hydroxychloroquine: } 500 \mathrm{mg} \\
\text { twice daily for } 10 \text { days or } 200 \\
\mathrm{mg} 3 \text { times daily for } 10 \text { days }\end{array}$ & $30,31,121$ \\
\hline Umifenovir & Antiviral agent & $\begin{array}{l}\text { Hemagglutinin inhibitor, which inhibits virus } \\
\text { membrane fusion with host cell }\end{array}$ & $\begin{array}{l}200 \mathrm{mg} \text { every } 12 \text { hours for } 10 \\
\text { days }\end{array}$ & 65,66 \\
\hline Ribavirin & Antiviral agent & $\begin{array}{l}\text { Inhibits protein synthesis via blocking IMPDH } \\
\text { during replication of virus }\end{array}$ & $\begin{array}{l}1200-2000 \mathrm{mg} \text { daily divided } \\
\text { into twice daily for } 5 \text { days }\end{array}$ & $52,54,55$ \\
\hline Remdesivir & Antiviral agent & Interferes with RNA polymerase & $\begin{array}{l}200 \mathrm{mg} \text { IV stat and then } 100 \mathrm{mg} \\
\text { daily for } 9 \text { days }\end{array}$ & 58,64 \\
\hline Interferon & Interferons & $\begin{array}{l}\text { Increases phagocyte activity of macrophages and } \\
\text { augments cytotoxicity of lymphocytes for viral } \\
\text { cells }\end{array}$ & $\begin{array}{l}5 \text { million units twice daily via } \\
\text { atomic nebulization or SQ } \\
\text { administration }\end{array}$ & $70,75,76$ \\
\hline Tocilizumab & $\begin{array}{l}\text { Antirheumatic/L- } \\
6 \text { receptor } \\
\text { antagonist }\end{array}$ & Antagonist of intracellular IL-6 receptor & $400 \mathrm{mg}$ IV infusion stat & 84 \\
\hline
\end{tabular}

Abbreviations: COVID-19, coronavirus disease 2019; HIV, human immunodeficiency virus; IMPDH, inosine monophosphate dehydrogenase; IV, intravenous; IL, interleukin. 
thus, we have to utilize the recommendations provided in transplant guidelines by scientific communities related to transplantation. For instance, the guideline provided by Massachusetts General Hospital has suggested that in non-critically ill kidney and liver transplant recipients, cyclosporine and tacrolimus doses should be reduced by $50 \%$ and their plasma concentrations should remain within 25-50 ng/mL and 3-5 ng/mL, respectively. Also, it has been recommended that antimetabolites, such as mycophenolate mofetil or mycophenolatesodium (Myfortic and CellCept) and azathioprine, should be stopped. At the same time, this guideline has recommended stopping all immunosuppressants in critically ill patients and administering prednisolone, but the dose has not been mentioned.${ }^{11}$ Meanwhile, the American Association for the Study of Liver Diseases (AASLD) has announced that there is no need to discontinue or decrease the dose of immunosuppressants in non-critically ill patients. ${ }^{12}$

In one case report regarding the successful treatment of a kidney transplant recipient with pneumonia caused by SARS-CoV-2 in China, all the immunosuppressants were stopped and the patient received $5 \mathrm{~g}$ intravenous immunoglobulin (IVIG) on the first day and then $10 \mathrm{~g} /$ day for the next 11 days, with $40 \mathrm{mg}$ /day methylprednisolone for 12 days and 5 million units/day interferon as atomization inhalation. ${ }^{13}$ However, using corticosteroids in the management of patients with acute respiratory distress syndrome (ARDS) or those affected with COVID-19 is controversial. ${ }^{14}$ The WHO advises against the use of corticosteroids for the management of severe acute respiratory infection when SARS-CoV-2 is suspected, unless indicated for another reason, such as an asthma attack or reversible septic shock. ${ }^{15,16}$ Inhibition of the immune response, reduction in pathogen clearance and an increase in viral shedding have been observed following the use of corticosteroids. ${ }^{17,18}$ Considering that adverse clinical outcomes and increased mortality and morbidity following the administration of corticosteroids in patients with respiratory infections caused by respiratory syncytial virus (RSV), influenza, SARS-CoV-1, or MERS-CoV may be due to an increased risk of secondary bacterial infections, their use for the prevention of disease progression or its treatment remains under discussion. ${ }^{19}$

In this regard, more precautions should be taken in transplant patients, because these agents are the main components of immunosuppression and their abrupt discontinuation may lead to an increased risk of acute rejection or flares in some liver transplant situations, such as autoimmune hepatitis. So, the AASLD suggests avoiding high doses of corticosteroids in these patients, and whenever the dose reduction is unavoidable, a minimum dose of $10 \mathrm{mg} /$ day prednisone should be considered to avoid adrenal insufficiency. ${ }^{12}$

Considering the pulmonary adverse effects of mammalian target of rapamycin (mTOR) inhibitors (ie, sirolimus and everolimus), including drug-induced pneumonitis and interstitial lung disease, ${ }^{20}$ it is reasonable to stop mTOR inhibitors and substitute them with calcineurin inhibitors (CNIs). ${ }^{20}$

So far, no specific regimen has been suggested for acute rejection episodes in liver and kidney transplant patients suffering from COVID-19, but considering the positive role of IVIG in the management of patients with COVID-19 in some experiences, administering IVIG as part of the treatment of antibody-mediated acute rejection in kidney transplant patients may be useful. ${ }^{21,22}$ As mentioned earlier in this section, the decrease in immunosuppression in transplant recipients leads to an increase in rejection risk. Thus, modification of the immunosuppression regimen should be rational and individualized.

Another important issue to be considered is that SARSCoV-2 can present as renal or hepatic impairment and it is necessary to differentiate these clinical manifestations from rejection episodes in liver or kidney recipients. According to the affinity between SARS-CoV-2 and angiotensin-converting enzyme-2 (ACE-2) receptors, which are enriched in the lung, liver, and biliary systems, an increase in liver enzymes, such as aspartate transaminase (AST), alanine transaminase (ALT), alkaline phosphatase (ALP), and gamma-glutamyl transferase (GGT), was seen in patients affected with COVID-19. ${ }^{23,25}$ The incidence of elevated liver enzymes in these patients ranges from $14 \%$ to $53 \%{ }^{26}$ Features of renal impairment, such as massive albuminuria, hematuria, and elevation in blood urea nitrogen or serum creatinine, are also present in these patients, with an incidence ranging between $14.1 \%$ and $44 \%{ }^{27}$ Therapeutic options for the management of liver or kidney injury following COVID-19 include limiting the use of hepatotoxic medications such as acetaminophen for fever management. Using compounds such as glycyrrhizic acid, owing to its steroid-like characteristics, could reduce hepatocyte inflammation to some extent. ${ }^{28}$ Also, one stud suggested using ursodeoxycholic acid and S-adenosylmethionine for the improvement of cholestatic liver injury caused by COVID-19. ${ }^{29}$ 


\section{Drug-Drug Interactions and Side Effects}

The suggested drug regimens for the treatment of COVID-19 have several drug-drug interactions and adverse drug reactions regarding immunosuppressive medications, which are mentioned in Table 2. These points are discussed in more detail below.

\section{Chloroquine Phosphate or Hydroxychloroquine}

Chloroquine phosphate or hydroxychloroquine, which has antimalarial characteristics, is one of the drugs used for the management of COVID-19 owing to its inhibitory effect on viral replication and its appropriate lung permeability. ${ }^{30,31}$ The suggested dose for chloroquine and hydroxychloroquine is $500 \mathrm{mg}$ twice daily for 10 days and $400 \mathrm{mg}$ daily for $10-14$ days, respectively. ${ }^{30}$ If hydroxychloroquine is used in combination with lopinavir/ritonavir, a loading dose of $200 \mathrm{mg}$ twice daily should be administered on the first day, then hydroxychloroquine should be discontinued and lopinavir/ritonavir initiated. An increase in liver enzymes, particularly when used concurrently with hepatotoxic drugs, gastrointestinal upset, and hemolytic anemia in patients with glucose-6-phosphate dehydrogenase (G6P) deficiency are important adverse effects of this drug. ${ }^{32}$ This drug can cause QT prolongation, too. So, prior to initiating this medication, the risk factors for QT prolongation, including hypomagnesemia, hypokalemia, and cardiomyopathy, should be evaluated and eliminated if possible. ${ }^{33}$ This adverse effect can also occur when chloroquine or hydroxychloroquine is used in combination with lopinavir/ritonavir, another drug used for the management of COVID-19, or some other QTc-prolonging medications, including antipsychotics (eg, pimozide) or cardiac medications (eg, digoxin). Occasional headaches, dizziness, loss of appetite, and maculopathy (in long-term use) are other adverse effects of this drug. ${ }^{34}$

Regarding the interactions between these drugs and immunosuppressants, it should be mentioned that chloroquine and hydroxychloroquine, as well as CNIs and mTor inhibitors, can cause QT prolongation. Furthermore, everolimus is a CYP3A4 inhibitor and can theoretically increase hydroxychloroquine and chloroquine concentration, and potentiates the QT-prolonging effect of these drugs. Cyclosporine concentration is also affected by hydroxychloroquine and chloroquine by inhibiting their metabolism through the inhibition of CYP3A4. Therefore, the cyclosporine level should be monitored periodically and the dose may be decreased if necessary. ${ }^{35,36}$ Removal of the drug by hemodialysis is negligible. It is suggested that $50 \%$ of the usual dose should be administered in patients with a glomerular filtration rate (GFR) $<10 \mathrm{~mL} / \mathrm{min}$, but $100 \%$ of the usual dose is recommended for patients on continuous renal replacement therapy (CRRT). ${ }^{37,38}$

\section{Lopinavir/Ritonavir}

Another drug of interest in the management of COVID-19 is lopinavir/ritonavir. Lopinavir is a protease inhibitor (PI) which has been used for years in the treatment of human immunodeficiency virus (HIV). Ritonavir increases the plasma half-life of lopinavir due to its inhibition of CYP450 enzymes. ${ }^{39}$ Some previous studies have shown positive results in using this drug against SARS and MERS. ${ }^{122,123}$ Thus, this drug has drawn medical attention for the management of COVID-19. ${ }^{40}$ Although some studies have reported positive effects of this drug on COVID$19,{ }^{21,41}$ a recently published article questioned its efficacy. ${ }^{42}$ Based on limited studies, using lopinavir as monotherapy or in combination with umifenovir (Arbidol ${ }^{\circledR}$ ), ribavirin, or interferon could help in the management of patients with COVID-19; ${ }^{21}$ however, a clinical trial did not demonstrate any superiority of lopinavir monotherapy over standard care supportive therapy. ${ }^{42}$ Therefore, further evaluations are required regarding its efficacy and safety.

So far, few studies have been conducted regarding the use of this drug in liver and kidney transplant patients, but if it is administered to this population, its adverse effects and interactions with immunosuppressants and other medications used in transplant patients, such as fluoroquinolones for the treatment of Gram-negative infections, should be considered. Although gastrointestinal upset, including nausea and vomiting, is the most important adverse effect of this drug, ${ }^{39}$ QT prolongation in combination with other medications used in the COVID-19 treatment regimen is also an issue of concern. Thus, it should be prescribed cautiously in patients with significant risk factors, such as previous second- and third-degree heart block. ${ }^{43} \mathrm{~A}$ rise in liver enzymes, particularly in decompensated cirrhosis, and pancreatitis have also been reported with its use in HIV patients. ${ }^{39}$ Ritonavir is an inhibitor of CYP3A4 and to a lesser extent CYP2D6, as well as an inhibitor of intestinal glycoprotein P. ${ }^{44}$ The majority of immunosuppressants are metabolized by CYP450 isoenzymes and eliminated via glycoprotein P. For instance, tacrolimus and cyclosporine 
Table 2 Drug Interactions, Side Effects, and Pharmacotherapeutic Considerations with COVID-19 Medications in Transplant Patients

\begin{tabular}{|c|c|c|c|}
\hline Drugs & Side Effects & $\begin{array}{l}\text { Drug-Immunosuppressant Interactions } \\
\text { (Risk Rating) }\end{array}$ & Considerations \\
\hline Lopinavir/Ritonavir & $\begin{array}{l}\text { Gl upset, including } N / N \text {, skin rash, } \\
\text { hypercholesterolemia, increased } \\
\text { serum TGs, increased liver } \\
\text { enzymes, diarrhea, abdominal pain, } \\
\text { dysgeusia, URT infection }\end{array}$ & $\begin{array}{l}\text { May increase serum concentration of everolimus } \\
\text { (category=X); concurrent use should be avoided } \\
\text { May increase serum concentration of } \\
\text { cyclosporine and tacrolimus (category=D); dose } \\
\text { reduction or prolongation of dosing interval and } \\
\text { monitoring serum concentrations should be } \\
\text { considered } \\
\text { May increase serum concentration of Sirolimus } \\
\text { (category=D); consider avoiding concurrent use } \\
\text { Recommended dose of tacrolimus is } 0.5 \mathrm{mg} \text { every } \\
5-7 \text { days and its plasma concentration should be } \\
\text { maintained between } 6 \text { and } 8 \mathrm{ng} / \mathrm{mL} \text {. } \\
\text { If daily administration of tacrolimus is preferred, } \\
\text { the dose of } 0.03-0.08 \mathrm{mg} \text { daily or to } \mathrm{I} / 20 \text { th- } \mathrm{I} / \\
50 \text { th reduction in daily dose is recommended. } \\
\text { Cyclosporine has less severe drug interactions } \\
\text { with Pls than tacrolimus Cyclosporine dose } \\
\text { should be reduced to } \mathrm{I} / 5 \text { th total daily dose to } \\
\text { achieve } 100-200 \mathrm{ng} / \mathrm{mL} \text { (eg, } 25 \mathrm{mg} \text { every I-2 } \\
\text { days); daily plasma concentration measurement is } \\
\text { also recommended }\end{array}$ & $\begin{array}{l}\text { No dose adjustment is suggested in } \\
\text { the manufacturer's labeling for } \\
\text { renal and hepatic impairment; use } \\
\text { with caution } \\
\text { Once-daily dosing in hemodialysis } \\
\text { patients should be avoided } \\
\text { May prolong QT and PR intervals } \\
\text { Metabolized by CYP3A4 and } \\
\text { potently inhibits this isoenzyme } \\
\text { and CYP2D6 to a lesser extent }\end{array}$ \\
\hline $\begin{array}{l}\text { Chloroquine/ } \\
\text { Hydroxychloroquine }\end{array}$ & $\begin{array}{l}\text { Retinopathy and maculopathy } \\
\text { (occurred in long-term use), } \\
\text { cardiomyopathy resulting in heart } \\
\text { failure, QT interval prolongation, } \\
\text { increased liver enzymes, bone } \\
\text { marrow suppression (rare), } \\
\text { hemolytic anemia, hypoglycemia, } \\
\text { Gl upset, occasional headaches, } \\
\text { dizziness, loss of appetite }\end{array}$ & $\begin{array}{l}\text { May increase serum concentration of } \\
\text { cyclosporine (category=D); monitoring for } \\
\text { increased serum concentrations and toxic effects } \\
\text { should be conducted }\end{array}$ & $\begin{array}{l}50 \% \text { of dose should be } \\
\text { administered in patients with GFR } \\
<10 \mathrm{~mL} / \mathrm{min} \text {, hemodialysis, and } \\
\text { peritoneal dialysis } \\
\text { The drug removal by hemodialysis } \\
\text { is negligible } \\
\text { No dose adjustment is necessary } \\
\text { during CRRT } \\
\text { No dose adjustment is suggested in } \\
\text { the manufacturer's labeling for } \\
\text { hepatic impairment; should be } \\
\text { used with caution } \\
\text { Should be used cautiously in } \\
\text { patients with G6PD deficiency due } \\
\text { to a potential for hemolytic anemia } \\
\text { Risk factors for QT prolongation, } \\
\text { including hypomagnesemia, } \\
\text { hypokalemia, and cardiomyopathy, } \\
\text { should be evaluated before } \\
\text { initiation, and eliminated if possible }\end{array}$ \\
\hline Umifenovir & No data available & No data available & $\begin{array}{l}\text { Metabolized by liver, particularly } \\
\text { CYP3A4, so it should be used with } \\
\text { caution in patients with liver failure } \\
\text { Its protein binding is high; thus, it } \\
\text { should be used cautiously in } \\
\text { patients receiving other } \\
\text { medications with high protein } \\
\text { binding, such as warfarin }\end{array}$ \\
\hline
\end{tabular}

(Continued) 
Table 2 (Continued).

\begin{tabular}{|c|c|c|c|}
\hline Drugs & Side Effects & $\begin{array}{l}\text { Drug-Immunosuppressant Interactions } \\
\text { (Risk Rating) }\end{array}$ & Considerations \\
\hline Ribavirin & $\begin{array}{l}\text { Headache, fatigue, loss of appetite, } \\
\text { diarrhea, abdominal pain, } \\
\text { dyspepsia, neutropenia, anemia, } \\
\text { lymphocytopenia, hemolytic } \\
\text { anemia, increased serum bilirubin, } \\
\text { musculoskeletal pain, influenza-like } \\
\text { symptoms, URT infections }\end{array}$ & $\begin{array}{l}\text { May increase serum concentrations of active } \\
\text { metabolites of azathioprine (category=D), } \\
\text { especially myelotoxic metabolites; it is suggested } \\
\text { to consider alternative agents; monitoring for } \\
\text { signs and symptoms of myelosuppression should } \\
\text { be conducted }\end{array}$ & $\begin{array}{l}\text { Dose adjustment should be } \\
\text { considered in renal impairment, but } \\
\text { optimal dose is not defined; } 400 \mathrm{mg} \\
\text { twice daily could be considered for } \\
\text { patients with mild renal impairment } \\
\text { (limited data); its use is not } \\
\text { recommended in patients with GFR } \\
<50 \mathrm{~mL} / \text { min due to increased risk of } \\
\text { hemolytic anemia } \\
\text { Its use is contraindicated in hepatic } \\
\text { decompensation (Child-Pugh class } \\
\text { B and C) } \\
\text { Hemolytic anemia I-2 weeks after } \\
\text { initiation of the drug is of great } \\
\text { importance (particularly in } \\
\text { cardiovascular patients) } \\
\text { Concurrent use with bone marrow } \\
\text { suppressants, eg, antimetabolites, } \\
\text { cotrimoxazole, ganciclovir, and } \\
\text { valganciclovir, causes } \\
\text { thrombocytopenia and pancytopenia }\end{array}$ \\
\hline Remdesivir & $\begin{array}{l}\text { Rash, diarrhea, hypotension, } \\
\text { increased liver enzymes }\end{array}$ & $\begin{array}{l}\text { Can induce CYP enzymes, including CYPIA2, } \\
\text { CYP2B6, and CYP3A4, but currently no data are } \\
\text { available regarding its drug-drug interactions. }\end{array}$ & $\begin{array}{l}\text { Remdesivir } 100 \mathrm{mg} \text { and } 5 \mathrm{mg} / \mathrm{mL} \\
\text { vials should be kept under } 30^{\circ} \mathrm{C} \\
\text { and at refrigerated temperatures } \\
\left(2-8^{\circ} \mathrm{C}\right) \text {, respectively, until time of } \\
\text { use. The } 5 \mathrm{mg} / \mathrm{mL} \text { vials can be } \\
\text { diluted with normal saline and } \\
\text { stored for maximum } 4 \text { hours at } \\
\text { room temperature or } 24 \text { hours at } \\
\text { refrigerated temperature }\end{array}$ \\
\hline Interferons & $\begin{array}{l}\text { Fatigue, headache, chills, } \\
\text { depression, malaise, neutropenia, } \\
\text { granulocytopenia, leukopenia, } \\
\text { anemia, thrombocytopenia, } \\
\text { increased serum AST, ALT, and } \\
\text { ALP, dyspnea, cough }\end{array}$ & No interactions & $\begin{array}{l}\text { It is suggested to permanently } \\
\text { discontinue the drug for severe } \\
\text { (grade } 3 \text { ) hepatic injury or hepatic } \\
\text { decompensation (Child-Pugh class } \\
\text { B and C [score }>6 \text { ]) }\end{array}$ \\
\hline Tocilizumab & $\begin{array}{l}\text { Hepatotoxicity, increased serum } \\
\text { ALT and AST, injection-site and } \\
\text { infusion-related reactions, } \\
\text { increased risk of URT infections, } \\
\text { neutropenia, leukopenia, } \\
\text { thrombocytopenia }\end{array}$ & $\begin{array}{l}\text { Concomitant use with rituximab should be } \\
\text { avoided (category=X) } \\
\text { May decrease serum concentration of tacrolimus } \\
\text { (category=C); monitoring for decreased levels } \\
\text { should be conducted }\end{array}$ & $\begin{array}{l}\text { No dose adjustment is necessary in } \\
\text { patients with } \mathrm{CrCl}<30 \mathrm{~mL} / \mathrm{min} \\
\text { No dose adjustment is suggested for } \\
\text { patients with hepatic impairment in } \\
\text { the manufacturer's labeling (has not } \\
\text { been studied) } \\
\text { Initiation of therapy in patients with } \\
\text { active hepatic disease or hepatic } \\
\text { impairment is not recommended }\end{array}$ \\
\hline
\end{tabular}

Abbreviations: TGs, triglycerides; GGT, gamma-glutamyl transferase; ALT, alanine transaminase; N/V, nausea and vomiting; URT, upper respiratory tract; PI, protease inhibitor; CYP, cytochrome; GI, gastrointestinal; CRRT, continuous renal replacement therapy; GFR, glomerular filtration rate; G6PD, glucose-6-phosphate dehydrogenase; AST, aspartate transaminase. 
are metabolized by this system, while mycophenolic acid is metabolized by uridine diphosphate glucuronosyltransferase (UGT) and has fewer interactions with antiretroviral therapy. ${ }^{44,46}$ Several studies have reported a significant increase in the plasma concentration of tacrolimus (8-20fold) when used with PIs. ${ }^{45,46}$ Therefore, based on the available evidence on HIV-positive kidney and liver recipients, who received tacrolimus and lopinavir concurrently, the recommended dose of tacrolimus is $0.5 \mathrm{mg}$ every 5-7 days and its plasma concentration should be maintained between 6 and $8 \mathrm{ng} / \mathrm{mL}^{44,47}$ If daily administration of tacrolimus is preferred, the dose of $0.03-0.08 \mathrm{mg}$ daily or a reduction to one-twentieth to one-fiftieth of baseline daily dose is recommended. ${ }^{12,46}$

Another CNI, cyclosporine, has less severe drug interactions with PIs than tacrolimus, but an increase in its plasma concentration, particularly when used with hydroxychloroquine, is of great importance. Thus, based on studies conducted on HIV-positive kidney and liver recipients who received cyclosporine and lopinavir/ritonavir concurrently, the cyclosporine dose should be reduced to one-fifth of the total daily dose to achieve $100-200 \mathrm{ng} / \mathrm{mL}$ as the target plasma concentration (eg, $25 \mathrm{mg}$ every 1-2 days), and daily plasma concentration measurement is also recommended. ${ }^{15,48}$

As mentioned earlier (see "Immunosuppressive Medications", above), temporary discontinuation of mTOR inhibitors in transplant patients with COVID-19 at the discretion of the transplant team is recommended. However, if they are continued, the drug interaction with PIs should be noted, and a 50-90\% reduction in dose of sirolimus and discontinuation of everolimus should be considered in concurrent use with PIs. ${ }^{49,51}$

\section{Ribavirin}

Ribavirin is a nucleotide/nucleoside analogue which is effective against a wide range of DNA and RNA viruses. ${ }^{52}$ The oral dosage form in combination with interferon is used in the treatment of chronic hepatitis $\mathrm{C}$ and the inhalation form is administered in the treatment of $\mathrm{RSV}^{53}$ It is considered as a promising agent in the management of COVID-19 because of effective clinical experience with this agent in MERS. ${ }^{54,55}$ If this drug is administered in transplant patients with COVID-19, the risk of drug interactions and adverse effects should be noted. Hemolytic anemia 1-2 weeks after the initiation of ribavirin, particularly in combination with interferons, is of great importance. Patients with cardiovascular comorbidity need more attention regarding this adverse effect. ${ }^{52}$

The concurrent use of ribavirin with bone marrow suppressant drugs, such as antimetabolites, cotrimoxazole, ganciclovir, and valganciclovir, which may be used in transplant patients, causes thrombocytopenia and pancytopenia. ${ }^{56}$ Considering renal elimination of ribavirin, its use is not recommended in patients with a GFR $<50 \mathrm{~mL} / \mathrm{min}$ because the risk of hemolytic anemia increases. ${ }^{57}$

\section{Remdesivir and Umifenovir (Arbidol)}

Remdesivir, which is an adenosine analogue and RNA polymerase inhibitor, acts as an antiviral agent and has been successful in the treatment of MERS-CoV and ebola in clinical and animal models. ${ }^{58,60}$ Thus, this drug has been mentioned in some studies as one of the treatment options for COVID-19 and its efficacy in COVID-19 is under investigation in clinical trials. ${ }^{61,124}$ Currently, nine clinical trials are being conducted regarding the safety and efficacy of remdesivir in patients with COVID-19. ${ }^{62}$ At this time, there is no widespread access to this drug and its use is limited to clinical trials, emergency treatment, and compassionate use requests, but its manufacturer, Gilead (Foster City), is trying to expand its access programs during the COVID-19 outbreak. $^{28,63}$ The suggested dose is $200 \mathrm{mg}$ stat and then $100 \mathrm{mg}$ daily for 9 days. ${ }^{64}$ Considering the limited studies on remdesivir, sufficient data regarding its side effects, drug interactions, and safety are not available and we should wait for further studies. No drug interactions are expected between remdesivir and immunosuppressants used in transplantation settings. However, considering the lack of knowledge regarding the safety of remdesivir coadministration with immunosuppressants, it is suggested that their blood concentrations should be closely monitored. ${ }^{15}$ The AASLD has warned about its hepatotoxic effects in transplanted patients. ${ }^{12}$

Umifenovir is another potential option for COVID-19 treatment. It is a broad-spectrum antiviral agent used in the treatment and prevention of influenza and it has in vitro activity against SARS-CoV-2. ${ }^{65}$ Studies published after the emergence of SARS-CoV-2 indicate that it has positive effects on COVID-19, in combination with other therapeutic options. The suggested dose in one study is $200 \mathrm{mg}$ every 12 hours for 10 days. ${ }^{66}$ In a case report regarding two kidney transplant patients with COVID-19 who were treated successfully, umifenovir was one of the therapeutic options. $^{67}$ 
Umifenovir is metabolized by the liver, particularly CYP3A4, so it should be used with caution in patients with liver failure. ${ }^{68}$ Its protein binding is high; thus, it should be used cautiously in patients receiving other medications with high protein binding. ${ }^{69}$ So far, no data are available regarding its effects when used concurrently with immunosuppressants.

\section{Interferon (IFN)}

IFN type I, such as IFN- $\alpha$ and IFN- $\beta$, and IFN type II, such as INF- $\gamma$, are considered important components of the host immune response to viral infections. ${ }^{70}$ Interferons have been used in the treatment of hepatitis $\mathrm{C}$ virus (HCV) in combination with ribavirin, owing to their positive effect on viral replication and immunomodulatory properties. ${ }^{71}$ After the emergence of SARS-CoV-1 in 2003 and MERS-CoV in 2013, studies regarding the effects of IFNs in their treatment have been conducted. ${ }^{72,74}$ Currently, IFNs are being studied for the treatment of COVID-19. IFNs have been used as nebulization or subcutaneous injections in these studies. ${ }^{75,76}$ Although it is too early to make judgments about the efficacy of IFNs in the management of COVID-19, the following points should be considered in kidney or liver transplant recipients with COVID-19 for whom INFs are initiated.

Long-term use of IFNs may cause bone marrow suppression, so it is recommended not to use these agents in severe neutropenia or thrombocytopenia. ${ }^{77}$ Moreover, their use can lead to hepatotoxicity. There are several reports of hepatoencephalopathy, jaundice, and acute liver failure in patients receiving IFN for the treatment of $\mathrm{HCV}^{78}$ At the same time, acute and chronic rejection, plasma cell hepatitis, and consequently graft failure have been reported in liver transplant recipients using pegylated interferon. ${ }^{79,81}$ Also, acute humoral rejection in kidney transplant recipients with $\mathrm{HCV}$ treated with IFN has been reported. ${ }^{82}$ Therefore, IFNs are not recommended in kidney and liver transplant recipients because of the risk of rejection.

\section{Interleukin (IL) Antagonists}

A hyperinflammatory syndrome, which presents with fulminant and fatal hypercytokinemia, is mentioned as COVID-19 pathogenesis in the majority of studies conducted in this regard. ${ }^{83}$ Some studies have mentioned positive effects of IL-1 inhibitor (anakinra) and IL-6 antagonist (tocilizumab) in COVID-19, and clinical trials are being conducted to evaluate the efficacy of these agents in the management of this disease. ${ }^{84,85}$ Thus, we should wait for the results of these studies. Studies on the safety of tocilizumab in transplantation have so far been restricted to steroid-refractory acute graft-versus-host disease (GVHD) ${ }^{86,125}$ and studies regarding the safety of this agent in kidney and liver transplantation are limited. Although studies on the efficacy and safety of tocilizumab in transplantation are scarce, some case reports have indicated that the use of monotherapy or combination therapy with tocilizumab improved the status of transplant recipients with COVID-19. ${ }^{85,87}$ It is worth mentioning that some aspects of tocilizumab administration, such as time of initiation (early vs late phase), route of administration (subcutaneous vs intravenous), and dose, are not clear yet, and we have to wait for the results of clinical trials. ${ }^{88}$ We found case reports mentioning liver damage and fulminant liver failure due to hepatitis B reactivation following tocilizumab therapy. ${ }^{89,91}$ However, there are some studies reporting successful treatment by tocilizumab of chronic antibody-mediated rejection in kidney transplant patients. ${ }^{86,126}$ Considering the specific adverse effects of tocilizumab, including upper respiratory tract infections, cardiovascular complications, and hepatic failure, ${ }^{92}$ it seems that until an official announcement of the results of ongoing studies, its use in transplant patients with COVID-19 is debatable.

\section{Other Considerations}

Sometimes, medications other than antivirals are used for symptomatic therapy or supportive care in COVID-19 patients. For the management of fever, myalgia, or headache caused by COVID-19 or by medication such as hydroxychloroquine, acetaminophen (paracetamol) is recommended as the first line agent, but acetaminopheninduced hepatotoxicity should be noted and the dose should be no more than $2 \mathrm{~g} /$ day. $^{12}$

Regarding the use of non-steroidal anti-inflammatory drugs (NSAIDs) in COVID-19 patients, no conclusive evidence is available. The mechanism of action of NSAIDs includes inhibition of cyclooxygenase (COX)1/COX2. These enzymes are responsible for the production of prostaglandins (PGs), such as $\mathrm{PGE}_{2} / \mathrm{PGD}_{2}$ and $\mathrm{PGI}_{2}$, which can promote and restrain inflammation. ${ }^{93}$ It is reported in one study that inflammation worsens following NSAID administration in COVID-19 patients, particularly those receiving ibuprofen. ${ }^{94}$ In one study, ibuprofen induced overexpression of ACE2 in diabetic rats. ${ }^{95}$ This effect can theoretically worsen the inflammatory course in patients suffering from COVID-19. ${ }^{96}$ However, some studies have concluded that owing to the anti-influenza properties of naproxen, ${ }^{97,98}$ it 
may be effective in COVID-19 patients. ${ }^{99}$ Also, considering the antiviral activity of indomethacin on coronavirus replication in vitro, it may be effective in COVID-19 patients. ${ }^{100}$ It is too early to make judgments about the effects of NSAIDs in the management of COVID-19 patients, and particularly transplant recipients, and we should wait for the results of ongoing studies, ${ }^{101}$ but the following points should be considered in the management of COVID-19 in kidney and liver transplant recipients.

Administration of NSAIDs in kidney transplant patients increases the risk of acute kidney injury (AKI) owing to their mechanism of action (inhibition of PG synthesis) and decrease in renal blood flow. ${ }^{102}$ The risk of AKI increases with the concurrent use of CNIs as the basis of immunosuppression in kidney transplant recipients. ${ }^{103}$ Also, concern exists regarding NSAID administration in liver transplant patients, particularly due to diclofenac liver injury. ${ }^{104}$ Thus, caution should be applied when administering NSAIDs in transplant recipients.

Another complication in patients with COVID-19 is nausea and vomiting $(\mathrm{N} / \mathrm{V})$. Serotonin antagonists $\left(5-\mathrm{HT}_{3}\right.$ receptor antagonists), dopamine antagonists, NK1 antagonists, and antihistamines are common drugs used for the management of $\mathrm{N} / \mathrm{V}^{105}$ Considering polypharmacy in patients with COVID-19, special attention should be given to drug interactions between antiemetics and other administered medications when treating $\mathrm{N} / \mathrm{V}$ in this population. For instance, the risk of QT prolongation is high in concurrent use of lopinavir/ritonavir, hydroxychloroquine, and serotonin antagonists, such as ondansetron and granisetron, or NK antagonists, such as aprepitant, and it is better to avoid their concurrent use. ${ }^{106}$ Furthermore, serotonin syndrome is predictable in concurrent use of serotonin antagonists with some common medications in critically ill patients, such as linezolid and fentanyl. ${ }^{107,108}$ Therefore, considering the safety of antiemetics, it is recommended to use antihistamines, such as diphenhydramine or dimenhydrinate, in patients with COVID-19. Also, it is advised to administer medications such as lopinavir/ritonavir after meals, and to insert an interval of at least 1 hour between these agents and emetogenic drugs, such as oseltamivir.

Dry cough is the main complaint of patients with COVID-19. Dextromethorphan, guaifenesin, codeine, and levocloperastine are safe in majority of patients and do not have any potential drug-drug interactions. ${ }^{109,110}$ However, the risk of serotonin syndrome with high-dose administration or prolonged use of dextromethorphan or other agents that increase serotonin should be noted. ${ }^{111}$
In transplant patients with cardiovascular diseases and COVID-19, it is necessary to continue cardiovascular medications. Based on animal laboratory studies, ACE2 receptors in the lung are binding sites for SARS-CoV-2. At first, the hypothesis was considered that taking ACE inhibitors (ACEIs) or angiotensin II receptor blockers (ARBs) can worsen the pulmonary function of patients with COVID$19,{ }^{112}$ but further studies demonstrated that ACEIs or ARBs can be considered as potential therapeutic options for the management of patients with COVID-19. ${ }^{113,127,128}$ Therefore, cardiovascular disease societies recommend that patients taking ACEIs or ARBs continue receiving their treatment and avoid the abrupt discontinuation of these drugs due to adverse effects on the course of COVID-19 disease. ${ }^{113}$

Statins are another prescribed class of medications discussed in patients with COVID-19. Considering their antiinflammatory properties, positive clinical experience with statins in the improvement of ARDS in patients with ebola and MERS, and their effect in upregulation of the activity of the ACE2 pathway, some reports have recommended their use in patients with COVID-19. ${ }^{114,116}$ However, some studies do not recommend the initiation or routine use of statins in patients with COVID-19 owing to the paradoxical effects of statins for improving lung function in patients with viral infections and their potential side effects. The American College of Cardiology recommends statin therapy only for patients with cardiovascular adverse effects caused by COVID-19 or patients with clinical atherosclerotic cardiovascular disease (ASCVD) or diabetes, or those at high risk of ASCVD. ${ }^{117,129,130}$ We should wait for further studies regarding the prescription of statins in kidney and liver transplant patients with COVID-19. Also, the side effects of statins, such as a rise in liver enzymes, myalgia, or, in more severe cases, rhabdomyolysis, should be considered. Considering drug interactions between immunosuppressants and statins, it seems that tacrolimus is a safer option than cyclosporine in concurrent use of atorvastatin. ${ }^{118,119}$ It is worth mentioning that most statins are metabolized via CYT P450 isoenzymes, particularly 3A4, as well as P-glycoproteins. The coadministration of PIs, such as lopinavir and darunavir, and their pharmacokinetic enhancers, such as ritonavir and cobicistat, with statins leads to increased statin levels and their adverse effects. Simvastatin or lovastatin should not be administered concomitantly with ritonavir/cobicistat-boosted PIs. The maximum recommended daily dose of atorvastatin and simvastatin is 20 and $10 \mathrm{mg}$, respectively, when coadministered with ritonavir/cobicistat-boosted PIs. ${ }^{120}$ 


\section{Conclusion}

The maintenance of the transplanted graft and its proper function is of great importance in patients with COVID-19. With regard to receiving immunosuppressants and polypharmacy, treatment options should be chosen with prudence in these patients. It is suggested that mTOR inhibitors be stopped throughout the course of COVID-19 and substituted with CNIs. Also, close therapeutic drug monitoring of immunosuppressants should be conducted in this population. Considering drug-drug interactions and adverse effects of medications used for the treatment of COVID-19, such as QT prolongation, the dose reduction of some immunosuppressants or avoidance of their administration should be considered in transplant recipients with COVID-19. QT prolongation should be considered when using hydroxychloroquine or lopinavir/ritonavir in combination with other QTc-prolonging drugs, such as antipsychotics and cardiac medications. We should wait for further clinical trials and multicenter studies to evaluate the safety and efficacy of treatment options for COVID-19 in transplant patients.

\section{Disclosure}

The authors report no conflicts of interest in this work.

\section{References}

1. Salzberger B, Glück T, Ehrenstein B. Successful containment of COVID-19: the WHO-Report on the COVID-19 outbreak in China. Infection. 2020;48(2):151-153. doi:10.1007/s15010-020-01409-4

2. Wang D, Hu B, Hu C, et al. Clinical characteristics of 138 hospitalized patients with 2019 novel coronavirus-infected pneumonia in Wuhan, China. JAMA. 2020;323(11):1061-1069. doi:10.1001/jama.2020.1585

3. WHO. Coronavirus disease (COVID-2019) situation reports. Available from: https://www.who.int/emergencies/diseases/novel-coronavirus2019/situation-reports/. Accessed 29 Mar 2020.

4. Boeckh M. The challenge of respiratory virus infections in hematopoietic cell transplant recipients. Br J Haematol. 2008;143(4):455467. doi:10.1111/j.1365-2141.2008.07295.x

5. Garbino J, Crespo S, Aubert JD, et al. A prospective hospital-based study of the clinical impact of non-severe acute respiratory syndrome (Non-SARS)-related human coronavirus infection. Clin Infect Dis. 2006;43(8):1009-1015. doi:10.1086/507898

6. Fernández-Ruiz M, Andrés A, Loinaz C, et al. COVID-19 in solid organ transplant recipients: a single-center case series from Spain. $\mathrm{Am}$ $J$ Transplant. 2020. doi:10.1111/ajt.15929

7. Angelico R, Trapani S, Manzia TM, Lombardini L, Tisone G, Cardillo M. The COVID-19 outbreak in Italy: initial implications for organ transplantation programs. Am J Transplant. 2020. doi:10.1111/ajt.15904

8. Vazin A, Fereidooni M. Determining frequency of prescription, administration and transcription errors in internal intensive care unit of Shahid Faghihi Hospital in Shiraz with direct observation approach. Iran J Pharmaceut Sci. 2012;8(3):189-194.

9. Chan KW, Wong VT, Tang SCW. COVID-19: an update on the epidemiological, clinical, preventive and therapeutic evidence and guidelines of integrative chinese-western medicine for the management of 2019 novel coronavirus disease. Am J Chin Med (Gard City N Y). $2020 ; 1-26$.
10. Sabrina VL et al. Interim clinical guidance for Patients suspected of/confirmed with COVID-19 in Belgium. 19 March 2020. Available from: https://epedimio.wiv-isp.be/ID/Covi-19/COVID19_Interim_Guidelines_Treatment/.Accessed March 25, 2020.

11. Massachusetts General Hospital. Department of Medicine COVID19 Treatment Guidance. 29 March 2020. Available from: https:// www.massgeneral.org/news/coronavirus/coronavirus-media-cover age/.Accessed March, 292020.

12. American Association for the Study of Liver Diseases. Clinical Insights for Hepatology and Liver Transplant Providers During the COVID-19 Pandemic. March 23, 2020. Available from: https://www.aasld.org/sites/default/files/2020-03/AASLDCOVID19-ClinicalInsights-3.23.2020-FINAL-v2.pdf. Accessed March 26, 2020.

13. Zhu L, Xu X, Ma K, et al. Successful recovery of COVID-19 pneumonia in a renal transplant recipient with long-term immunosuppression. Am J Transplant. n/a(n/a).

14. Vazin A, Mojtahedzadeh M, Salehifar E, et al. Future drugs for treatment of acute respiratory distress syndrome. Int $J$ Pharmacol. 2005;1:9-16. doi:10.3923/ijp.2005.9.16

15. Elens L, Langman LJ, Hesselink DA, et al. Pharmacologic treatment of transplant recipients infected with SARS-CoV-2: considerations regarding therapeutic drug monitoring and drug-drug interactions. Ther Drug Monit. 2020;42(3):360-368. doi:10.1097/ FTD.0000000000000761

16. Organization WH. Clinical Management of Severe Acute Respiratory Infection When Novel Coronavirus (2019-Ncov) Infection Is Suspected: Interim Guidance, 28 January 2020. World Health Organization; 2020.

17. Wu C, Chen X, Cai Y, et al. Risk factors associated with acute respiratory distress syndrome and death in patients with coronavirus disease 2019 pneumonia in Wuhan, China. JAMA Intern Med. 2020. doi:10.1001/jamainternmed.2020.0994

18. Arkas J Internet book of critical care. From EMCrit Project website. Available from: https://emcrit.org/ibcc/COVID19/ Accessed. April 7, 2020.

19. Russell CD, Millar JE, Baillie JK. Clinical evidence does not support corticosteroid treatment for 2019-nCoV lung injury. The Lancet. 2020;395(10223):473-475. doi:10.1016/S0140-6736(20) 30317-2

20. Nguyen LS, Vautier M, Allenbach Y, et al. Sirolimus and mTOR inhibitors: a review of side effects and specific management in solid organ transplantation. Drug Safety. 2019;1-13.

21. Liu F, Xu A, Zhang Y, et al. Patients of COVID-19 may benefit from sustained lopinavir-combined regimen and the increase of eosinophil may predict the outcome of COVID-19 progression. Int J Infect Dis. 2020.

22. Cao W, Liu X, Bai T, et al. High-dose intravenous immunoglobulin as a therapeutic option for deteriorating patients with Coronavirus Disease 2019. Paper presented at: Open Forum Infectious Diseases2020.

23. Bangash MN, Patel J, Parekh D. COVID-19 and the liver: little cause for concern. The Lancet Gastroenterol Hepatol. 2020;5 (6):529-530. doi:10.1016/S2468-1253(20)30084-4

24. Xu L, Liu J, Lu M, Yang D, Zheng X. Liver injury during highly pathogenic human coronavirus infections. Liver Int. 2020;40 (5):998-1004. doi:10.1111/liv.14435

25. Rismanbaf A, Zarei S. Liver and kidney injuries in COVID-19 and their effects on drug therapy; a letter to editor. Arch Acad Emerg Med. 2020;8(1):e17.

26. Zhang C, Shi L, Wang F-S. Liver injury in COVID-19: management and challenges. The Lancet Gastroenterol Hepatol. 2020;5 (5):428-430. doi:10.1016/S2468-1253(20)30057-1

27. Naicker S, Yang C-W, Hwang S-J, Liu B-C, Chen J-H, Jha V. The novel coronavirus 2019 epidemic and kidneys. Kidney Int. 2020;97 (5):824-828. doi:10.1016/j.kint.2020.03.001 
28. Chinese Medical Association Hepatology drug-induced liver disease study group. Drug-induced liver injury diagnosis and treatment guidelines. J Hepatol. 2015;23(11):810-820. doi:10.3760/ cma.j.issn.1007-3418.2015.11.004.

29. $\mathrm{Hu}$ L, Wang W, Zhu Q, Yang L. Novel coronavirus pneumonia related liver injury: etiological analysis and treatment strategy. Zhonghua Gan Zang Bing Za Zhi= Zhonghua Ganzangbing Zazhi= Chinese Journal of Hepatology. 2020;28:E001.

30. Cortegiani A, Ingoglia G, Ippolito M, Giarratano A, Einav S. A systematic review on the efficacy and safety of chloroquine for the treatment of COVID-19. J Crit Care. 2020;57:279-283. doi:10.1016/j.jcrc.2020.03.005

31. Sahraei Z, Shabani M, Shokouhi S, Saffaei A. Aminoquinolines against coronavirus disease 2019 (COVID-19): chloroquine or Hydroxychloroquine. Int J Antimicrob Agents. 2020;55(4):105945. doi:10.1016/j.ijantimicag.2020.105945

32. Costedoat-Chalumeau N, Dunogué B, Morel N, Le Guern V, Guettrot-Imbert G. Hydroxychloroquine: a multifaceted treatment in lupus. La Presse Médicale. 2014;43(6):e167-e180. (). doi:10. 1016/j.lpm.2014.03.007

33. O'Laughlin JP, Mehta PH, Wong BC. Life threatening severe QTc prolongation in patient with systemic lupus erythematosus due to hydroxychloroquine. Case Rep Cardiol. 2016;2016.

34. Ruiz-Irastorza G, Ramos-Casals M, Brito-Zeron P, Khamashta MA. Clinical efficacy and side effects of antimalarials in systemic lupus erythematosus: a systematic review. Ann Rheum Dis. 2010;69 (01):20-28. doi:10.1136/ard.2008.101766

35. Sarzi-Puttini P, D'Ingianna E, Fumagalli M, et al. An open, randomized comparison study of cyclosporine A, cyclosporine $\mathrm{A}+$ methotrexate and cyclosporine $\mathrm{A}+$ hydroxychloroquine in the treatment of early severe rheumatoid arthritis. Rheumatol Int. 2005;25(1):1522. doi:10.1007/s00296-003-0384-2

36. Ikitimur B, Cosansu K, Karadag B, et al. Long-term impact of different immunosuppressive drugs on QT and PR intervals in renal transplant patients. Ann Noninvasive Electrocardiol. 2015;20 (5):426-432. doi:10.1111/anec.12225

37. Bethel M, Yang FM, Li S, et al. Hydroxychloroquine in patients with systemic lupus erythematosus with end-stage renal disease. $J$ Investigative Med. 2016;64(4):908-910. doi:10.1136/jim-2016000065

38. Lexi-Drugs. Lexicomp [Internet]. Hudson, OH: Wolters Kluwer Health, Inc. 1978-2020. Chloroquine; [2020 Mar 25] Available from http://online.lexi.com. Accessed June 16, 2020.

39. Cvetkovic RS, Goa KL. Lopinavir/Ritonavir. Drugs. 2003;63 (8):769-802. doi:10.2165/00003495-200363080-00004

40. Yao TT, Qian JD, Zhu WY, Wang Y, Wang GQ. A systematic review of lopinavir therapy for SARS Coronavirus and MERS coronavirus-a possible reference for coronavirus disease-19 treatment option. J Med Virol. 2020;92(6):556-563. doi:10.1002/ jmv.25729

41. Lim J, Jeon S, Shin H-Y, et al. Case of the index patient who caused tertiary transmission of COVID-19 infection in Korea: the application of lopinavir/ritonavir for the treatment of COVID-19 infected pneumonia monitored by quantitative RT-PCR. $J$ Korean Med Sci. 2020;35:6.

42. Cao B, Wang Y, Wen D, et al. A trial of lopinavir-ritonavir in adults hospitalized with severe Covid-19. N Engl J Med. 2020;382 (19):1787-1799. doi:10.1056/NEJMoa2001282

43. Liu J, Shah SK, Basu-Ray I, Garcia-Diaz J, Khalid K, Saeed M. QT prolongation in HIV-positive patients. Indian Heart J. 2019;71 (6):434-439. doi:10.1016/j.ihj.2019.11.259

44. Primeggia J, Timpone JG, Kumar PN. Pharmacologic issues of antiretroviral agents and immunosuppressive regimens in HIVinfected solid organ transplant recipients. Infect Dis Clin. 2013;27 (2):473-486. doi:10.1016/j.idc.2013.02.011
45. Van Maarseveen EM, Rogers CC, Trofe-Clark J, Van Zuilen AD, Mudrikova T. Drug-drug interactions between antiretroviral and immunosuppressive agents in HIV-infected patients after solid organ transplantation: a review. AIDS Patient Care STDS. 2012;26(10):568-581. doi:10.1089/apc.2012.0169

46. Bickel M, Anadol E, Vogel M, et al. Daily dosing of tacrolimus in patients treated with HIV-1 therapy containing a ritonavir-boosted protease inhibitor or raltegravir. J Antimicrob Chemother. 2010;65 (5):999-1004. doi:10.1093/jac/dkq054

47. Schonder KS, Shullo MA, Okusanya O. Tacrolimus and lopinavir/ ritonavir interaction in liver transplantation. Ann Pharmacother. 2003;37(12):1793-1796. doi:10.1345/aph.1D076

48. Badri PS, Parikh A, Coakley EP, et al. Pharmacokinetics of tacrolimus and cyclosporine in liver transplant recipients receiving 3 direct-acting antivirals as treatment for hepatitis $\mathrm{C}$ infection. Ther Drug Monit. 2016;38(5):640-645. doi:10.1097/FTD.000000000 0000315

49. Barau C, Blouin P, Creput C, Taburet A, Durrbach A, Furlan V. Effect of coadministered HIV-protease inhibitors on tacrolimus and sirolimus blood concentrations in a kidney transplant recipients. Fundam Clin Pharmacol. 2009;23(4):423-425. doi:10.1111/j.14728206.2009.00706.x

50. Jacob S, Nair AB. A review on therapeutic drug monitoring of the mTOR class of immunosuppressants: everolimus and sirolimus. Drugs Ther Perspect. 2017;33(6):290-301. doi:10.1007/s40267017-0403-0

51. Meziyerh S, Zwart TC, van Etten RW, et al. Severe COVID-19 in a renal transplant recipient: a focus on pharmacokinetics. Am J Transplant. 2020. doi:10.1111/ajt.15943

52. Nyström K, Waldenström J, Tang K-W, Lagging M. Ribavirin: pharmacology, multiple modes of action and possible future perspectives. Future Virol. 2019;14(3):153-160. doi:10.2217/fvl-20180166

53. Foolad F, Aitken SL, Shigle TL, et al. Oral versus aerosolized ribavirin for the treatment of respiratory syncytial virus infections in hematopoietic cell transplant recipients. Clin Infect Dis. 2019;68 (10):1641-1649. doi:10.1093/cid/ciy760

54. Arabi YM, Shalhoub S, Mandourah Y, et al. Ribavirin and interferon therapy for critically ill patients with middle east respiratory syndrome: a multicenter observational study. Clin Infect Dis. 2019.

55. Ramírez-Olivencia G, Estébanez M, Membrillo FJ, Del Carmen Ybarra M. Use of ribavirin in viruses other than hepatitis C. A review of the evidence. Enfermedades infecciosas y microbiologia clinica (English ed). 2019.

56. Kogiso T. Mycophenolate mofetil/ribavirin interaction. Reactions 2015;1561:125-134.

57. Brennan B, Wang K, Blotner S, et al. Safety, tolerability, and pharmacokinetics of ribavirin in hepatitis $\mathrm{C}$ virus-infected patients with various degrees of renal impairment. Antimicrob Agents Chemother. 2013;57(12):6097-6105. doi:10.1128/AAC.00608-13

58. Tchesnokov EP, Feng JY, Porter DP, Götte M. Mechanism of inhibition of Ebola virus RNA-dependent RNA polymerase by remdesivir. Viruses. 2019;11(4):326. doi:10.3390/v11040326

59. Sheahan TP, Sims AC, Leist SR, et al. Comparative therapeutic efficacy of remdesivir and combination lopinavir, ritonavir, and interferon beta against MERS-CoV. Nat Commun. 2020;11(1):114. doi:10.1038/s41467-019-13940-6

60. de Wit E, Feldmann F, Cronin J, et al. Prophylactic and therapeutic remdesivir (GS-5734) treatment in the rhesus macaque model of MERS-CoV infection. Proc Natl Acad Sci. 2020;117(12):67716776. doi:10.1073/pnas.1922083117

61. Li G, De Clercq E. Therapeutic Options for the 2019 Novel Coronavirus (2019-Ncov). Nature Publishing Group; 2020.

62. National US. ClinicalTrials. Gov. Institutes of Health. Available from: https://clinicaltrials.gov/. Accessed June 16, 2020. 
63. Beigel JH, Tomashek KM, Dodd LE, et al. Remdesivir for the treatment of Covid-19-preliminary report. N Engl J Med. 2020. doi:10.1056/NEJMoa2007764

64. Al-Tawfiq JA, Al-Homoud AH, Memish ZA. Remdesivir as a possible therapeutic option for the COVID-19. Travel Med Infect Dis. 2020;34:101615. doi:10.1016/j.tmaid.2020.101615

65. Blaising J, Polyak SJ, Pécheur E-I. Arbidol as a broad-spectrum antiviral: an update. Antiviral Res. 2014;107:84-94. doi:10.1016/j. antiviral.2014.04.006

66. Deng L, Li C, Zeng Q, et al. Arbidol combined with LPV/r versus LPV/ $r$ alone against Corona Virus Disease 2019: a retrospective cohort study. $J$ Infect. 2020;81(1):e1-e5. doi:10.1016/j.jinf.2020.03.002

67. Li Q, Cheng Q, Zhao Z, et al. Novel Coronavirus Infection and Acute Kidney Injury in Two Renal Transplant Recipients: Case Report. 2020.

68. Deng $\mathrm{P}$, Zhong $\mathrm{D}$, Yu K, Zhang $\mathrm{Y}$, Wang $\mathrm{T}$, Chen $\mathrm{X}$. Pharmacokinetics, metabolism, and excretion of the antiviral drug arbidol in humans. Antimicrob Agents Chemother. 2013;57(4):17431755. doi:10.1128/AAC.02282-12

69. Liu X, Chen X, Liu W, Zhang J, Bi K. Determination of plasma protein binding rate of arbidol. Chin J New Drugs Clin Remedies. 2007;26(2):115.

70. Jr B S, Mossel EC, Peters C, Garry RF. Interferon-beta and interferongamma synergistically inhibit the replication of severe acute respiratory syndrome-associated coronavirus (SARS-CoV). Virology. 2004;329(1):11-17. doi:10.1016/j.virol.2004.08.011

71. Younossi ZM, Stepanova M, Henry L, Nader F, Younossi Y, Hunt S. Adherence to treatment of chronic hepatitis C: from interferon containing regimens to interferon and ribavirin free regimens. Medicine. 2016;95(28):28. doi:10.1097/MD.0000000000004151

72. Cinatl Jr J Jr, Michaelis M, Scholz M, Doerr HW. Role of interferons in the treatment of severe acute respiratory syndrome. Expert Opin Biol Ther. 2004;4(6):827-836. doi:10.1517/14712598.4.6.827

73. Thiel V, Weber F. Interferon and cytokine responses to SARScoronavirus infection. Cytokine Growth Factor Rev. 2008;19 (2):121-132. doi:10.1016/j.cytogfr.2008.01.001

74. Falzarano D, De Wit E, Rasmussen AL, et al. Treatment with interferon- $\alpha 2 b$ and ribavirin improves outcome in MERS-CoVinfected rhesus macaques. Nat Med. 2013;19(10):1313-1317. doi: $10.1038 / \mathrm{nm} .3362$

75. Dong L, Hu S, Gao J. Discovering drugs to treat coronavirus disease 2019 (COVID-19). Drug Discov Ther. 2020;14(1):58-60. doi: $10.5582 /$ ddt.2020.01012

76. Cunningham A, Goh H, Koh D. Treatment of COVID-19: old tricks for new challenges. Crit Care. 2020;24.

77. Li L, Han D-K, Lu J. Interferon- $\alpha$ induced severe thrombocytopenia: a case report and review of the literature. World $J$ Gastroenterol. 2010;16(11):1414. doi:10.3748/wjg.v16.i11.1414

78. Fontana RJ, Hayashi P, Bonkovsky HL, et al. Presentation and outcomes with clinically apparent interferon beta hepatotoxicity. Dig Dis Sci. 2013;58(6):1766-1775. doi:10.1007/s10620-0122553-1

79. Levitsky J, Fiel MI, Norvell JP, et al. Risk for immune-mediated graft dysfunction in liver transplant recipients with recurrent $\mathrm{HCV}$ infection treated with pegylated interferon. Gastroenterology. 2012;142(5):1132-1139. doi:10.1053/j.gastro.2012.01.030

80. Saab S, Kalmaz D, Gajjar NA, et al. Outcomes of acute rejection after interferon therapy in liver transplant recipients. Liver Transplant. 2004;10(7):859-867. doi:10.1002/lt.20157

81. Selzner N, Guindi M, Renner EL, Berenguer M. Immune-mediated complications of the graft in interferon-treated hepatitis $\mathrm{C}$ positive liver transplant recipients. $J$ Hepatol. 2011;55(1):207-217. doi:10.1016/j.jhep.2010.11.012

82. Fraile P, Garcia-Cosmes P, Rosado C, Tabernero J. Interferon-alpha and its deleterious effects on kidney transplant: regarding one case. Nefrología (English Edition). 2009;29(4):366-367.
83. Mehta P, McAuley D, Brown M, Sanchez E, Tattersall R, Manson J. COVID-19: consider cytokine storm syndromes and immunosuppression. The Lancet. 2020;395(10229):1033-1034. doi:10.1016/S01406736(20)30628-0

84. Xu X, Han M, Li T, et al. Effective treatment of severe COVID-19 patients with tocilizumab. In: ChinaXiv: 20200300026.2020.

85. Fontana F, Alfano G, Mori G, et al. Covid-19 pneumonia in a kidney transplant recipient successfully treated with tocilizumab and hydroxychloroquine. Am J Transplant. 2020. doi:10.1111/ ajt.15935

86. Choi J, Aubert O, Vo A, et al. Assessment of Tocilizumab (AntiInterleukin-6 Receptor Monoclonal) as a potential treatment for chronic antibody-mediated rejection and transplant glomerulopathy in HLA-sensitized renal allograft recipients. Am $J$ Transplant. 2017;17(9):2381-2389. doi:10.1111/ajt.14228

87. Hammami MB, Garibaldi B, Shah P, et al. Clinical Course of COVID-19 in a liver transplant recipient on hemodialysis and response to tocilizumab therapy: a case report. Am J Transplant. 2020. doi:10.1111/ajt.15985

88. Tocilizumab in COVID-19 Pneumonia (TOCIVID-19) - ClinicalTrials. gov. Available from: https://clinicaltrials.gov/ct2/show/study/ NCT04317092?term=tocilizumab\&cond $=$ covid \&draw $=2 \&$ rank $=1$. Accessed March 24, 2020.

89. Anger F, Wiegering A, Wagner J, et al. Toxic drug-induced liver failure during therapy of rheumatoid arthritis with tocilizumab subcutaneously: a case report. Rheumatology. 2017;56(9):16281629. doi:10.1093/rheumatology/kex221

90. Hiura M, Abe S, Tabaru A, et al. Case of severe liver damage after the induction of tocilizumab therapy for rheumatoid vasculitis. Hepatol Res. 2011;41(5):492-496. doi:10.1111/j.1872-034X.2011.00793.x

91. Sonneveld MJ, Murad SD, van der Eijk A, de Man R. Fulminant liver failure due to Hepatitis B reactivation during treatment with tocilizumab. ACG Case Reports Journal. 2019;6(12):e00243. doi:10.14309/crj.0000000000000243

92. Bannwarth B, Richez C. Clinical safety of tocilizumab in rheumatoid arthritis. Expert Opin Drug Saf. 2011;10(1):123-131. doi:10. 1517/14740338.2011.537256

93. FitzGerald GA. Misguided drug advice for COVID-19. Science. 2020.

94. Day M. Covid-19: Ibuprofen Should Not Be Used for Managing Symptoms, Say Doctors and Scientists. British Medical Journal Publishing Group; 2020.

95. Qiao W, Wang C, Chen B, et al. Ibuprofen attenuates cardiac fibrosis in streptozotocin-induced diabetic rats. Cardiology. 2015;131(2):97-106. doi:10.1159/000375362

96. Favalli EG, Ingegnoli F, De Lucia O, Cincinelli G, Cimaz R, Caporali R. COVID-19 infection and rheumatoid arthritis: faraway, so close! Autoimmun Rev. 2020;19(5):102523. doi:10.1016/j.autrev.2020.102523

97. Tarus B, Bertrand H, Zedda G, Di Primo C, Quideau S, Slama-Schwok A. Structure-based design of novel naproxen derivatives targeting monomeric nucleoprotein of Influenza A virus. J Biomol Struct Dyn. 2015;33(9):1899-1912. doi:10.1080/07391102.2014.979230

98. Lejal N, Tarus B, Bouguyon E, et al. Structure-based discovery of the novel antiviral properties of naproxen against the nucleoprotein of influenza A virus. Antimicrob Agents Chemother. 2013;57 (5):2231-2242. doi:10.1128/AAC.02335-12

99. Zheng W, Fan W, Zhang S, et al. Naproxen exhibits broad anti-influenza virus activity in mice by impeding viral nucleoprotein nuclear export. Cell Rep. 2019;27(6):1875-1885. doi:10.1016/j.celrep.2019.04.053

100. Amici C, Di Coro A, Ciucci A, et al. Indomethacin has a potent antiviral activity against SARS coronavirus. Antivir Ther. 2006;11 (8): 1021.

101. Adnet F, Slama Schwok A Efficacy of addition of naproxen in the treatment of critically ill patients hospitalized for COVID-19 infection (ENACOVID); 2020. Available from: https://www.clinical trials.gov/ct2/show/NCT04325633. [Accessed May 4, 2020 
102. Chiasson JM, Fominaya CE, Gebregziabher M, Taber DJ. Longterm assessment of NSAID prescriptions and potential nephrotoxicity risk in adult kidney transplant recipients. Transplantation. 2019;103(12):2675-2681. doi:10.1097/TP.0000000000002689

103. Naesens M, Kuypers DR, Sarwal M. Calcineurin inhibitor nephrotoxicity. Clin J Am Soc Nephrol. 2009;4(2):481-508. doi:10.2215/ CJN.04800908

104. Sriuttha P, Sirichanchuen B, Permsuwan U. Hepatotoxicity of nonsteroidal anti-inflammatory drugs: a systematic review of randomized controlled trials. Int J Hepatol. 2018;2018.

105. Hesketh PJ, Kris MG, Basch E, et al. Antiemetics: american Society of Clinical Oncology clinical practice guideline update. J Clin Oncol. 2017;35(28):3240-3261. doi:10.1200/JCO.2017.74.4789

106. Krammes SK, Jacobs T, Clark JM, Lutes RE. Effect of intravenous ondansetron on the QT interval of patients' electrocardiograms. Pediatr Emerg Care. 2018;34(1):38-41. doi:10.1097/PEC.000000 0000000757

107. Warner ME, Naranjo J, Pollard EM, Weingarten TN, Warner MA, Sprung J. Serotonergic medications, herbal supplements, and perioperative serotonin syndrome. Can $J$ Anesth/J canadien d'anesthésie. 2017;64(9):940-946. doi:10.1007/s12630-017-0918-9

108. Shafiekhani M, Mirjalili M, Vazin A. Psychotropic drug therapy in patients in the intensive care unit-usage, adverse effects, and drug interactions: a review. Ther Clin Risk Manag. 2018;14:1799. doi:10.2147/TCRM.S176079

109. Satish K, Sholapuri D, Niranjane V, Garg S. Efficacy and safety of levocloperastine in the treatment of dry cough: a prospective observational study. $J$ Assoc Phys India. 2018;66:71.

110. Lai K, Shen H, Zhou X, et al. Clinical practice guidelines for diagnosis and management of cough - Chinese Thoracic Society (CTS) Asthma Consortium. J Thorac Dis. 2018;10(11):6314. doi:10.21037/jtd.2018.09.153

111. Taylor CP, Traynelis SF, Siffert J, Pope LE, Matsumoto RR. Pharmacology of dextromethorphan: relevance to dextromethorphan/quinidine $\left(\right.$ Nuedexta $\left.^{\circledR}\right)$ clinical use. Pharmacol Ther. 2016;164:170-182. doi:10.1016/j.pharmthera.2016.04.010

112. Diaz JH. Hypothesis: angiotensin-converting enzyme inhibitors and angiotensin receptor blockers may increase the risk of severe COVID-19. J Travel Med. 2020;27(3). doi:10.1093/jtm/taaa041

113. Kuster GM, Pfister O, Burkard T, et al. SARS-CoV2: should inhibitors of the renin-angiotensin system be withdrawn in patients with COVID-19? Eur Heart J. 2020;41(19):1801-1803. doi:10. 1093/eurheartj/ehaa235

114. Fedson DS, Opal SM, Rordam OM. Hiding in plain sight: an approach to treating patients with severe COVID-19 infection. mBio. 2020;11(2):2. doi:10.1128/mBio.00398-20

115. Fedson DS, Rordam OM. Treating Ebola patients: a 'bottom up'approach using generic statins and angiotensin receptor blockers. Int $J$ Infect Dis. 2015;36:80-84. doi:10.1016/j.ijid.2015.04.019

116. Yuan S. Statins may decrease the fatality rate of Middle East respiratory syndrome infection. mBio. 2015;6(4):e01120-01115. doi:10.1128/mBio.01120-15
117. ACC Clinical Bulletin. COVID-19 clinical guidance for the cardiovascular team. March 6, 2020. Available from: https://www.acc. org/latest-in-cardiology/features/ /media/Non-Clinical/Files-PDFsExcel-MS-Word-etc/2020/02/S20028-ACC-Clinical-BulletinCoronavirus.pdf $\% 20 \% 20 \% 20$ Access/.Accessed 25 March 2020.

118. Migliozzi DR, Asal NJ. Clinical controversy in transplantation: tacrolimus versus cyclosporine in statin drug interactions. Ann Pharmacother. 2020;54(2):171-177. doi:10.1177/1060028019871891

119. Amundsen R, Christensen H, Zabihyan B, Åsberg A. Cyclosporine A, but not tacrolimus, shows relevant inhibition of organic anion-transporting protein 1B1-mediated transport of atorvastatin. Drug Metabol Disposition. 2010;38(9):1499-1504. doi:10.1124/dmd.110.032268

120. Dashti-Khavidaki S, Khalili H. Considerations for statin therapy in patients with COVID-19. Pharmacotherapy. 2020;40(5):484-486. doi:10.1002/phar.2397

121. Gautret P, Lagier J-C, Parola P. et al. Hydroxychloroquine and azithromycin as a treatment of COVID-19: results of an openlabel non-randomized clinical trial. Int J Antimicrob Agents;2020. 105949. doi:10.1016/j.ijantimicag.2020.105949

122. Yao T-T, Qian J-D, Zhu W-Y, Wang YWang G-Q. A systematic review of lopinavir therapy for sars coronavirus and mers coronavirus - a possible reference for coronavirus disease-19 treatment option. J Med Virol. 2020;92(6):556-563. doi:10.1002/jmv.v92.6

123. Chu CM, Cheng VCCHung FN, et al. Role of lopinavir/ritonavir in the treatment of sars: initial virological and clinical findings. Thorax. 2004;59( 3):252-256. doi:10.1136/thorax.2003.012658.

124. Al-Homoud AHMemish ZA. Remdesivir as a possible therapeutic option for the covid-19. Travel Med Infect Dis. 2020;34:101615. doi:10.1016/j.tmaid.2020.101615

125. Kennedy GA, Varelias A, Vuckovic SLe Texier L. Addition of interleukin-6 inhibition with tocilizumab to standard graft-versushost disease prophylaxis after allogeneic stem-cell transplantation: a phase 1/2 trial. Lancet Oncol. 2014;15(13):1451-1459. doi:10.1016/S1470-2045(14)71017-4

126. Shin BH, Everly MJZhang H, et al. Impact of tocilizumab (anti-il6r) treatment on immunoglobulins and anti-hla antibodies in kidney transplant patients with chronic antibody-mediated rejection. Transplantation. 2020;104(4):856-863. doi:10.1097/TP.00000 00000002895.

127. Rico-Mesa JS, White AAnderson AS. Outcomes in patients with covid-19 infection taking acei/arb. Curr Cardiol Rep. 2020;22( 5 15): 5 15. doi:10.1007/s11886-020-01291-4

128. Meg J, Xiao GZhang J, et al. Renin-angiotensin system inhibitors improve the clinical outcomes of covid-19 patients with hypertension. Emerging Microbes \& Infections. 2020;9(1):757-760. doi:10.1080/22221751.2020.1746200

129. Shin J-Y, Eberg M, Ernst PFilion KB. Statin potency and the risk of hospitalization for community-acquired pneumonia. $\mathrm{Br} \mathrm{J}$ Clin Pharmacol. 2017;83(6):1319-1327. doi:10.1111/bcp.13208

130. Vinogradova Y, Coupland CHippisley-Cox J. Risk of pneumonia in patients taking statins: population-based nested case-control study. Br J Gen Pract. 2011;61(592):e742-748. doi:10.3399/bjgp1 $1 \mathrm{X} 606654$
Therapeutics and Clinical Risk Management

\section{Publish your work in this journal}

Therapeutics and Clinical Risk Management is an international, peerreviewed journal of clinical therapeutics and risk management, focusing on concise rapid reporting of clinical studies in all therapeutic areas, outcomes, safety, and programs for the effective, safe, and sustained use of medicines. This journal is indexed on PubMed Central, CAS,
EMBase, Scopus and the Elsevier Bibliographic databases. The manuscript management system is completely online and includes a very quick and fair peer-review system, which is all easy to use. Visit http://www.dovepress.com/testimonials.php to read real quotes from published authors. 